\title{
JOURNAL.RU
}

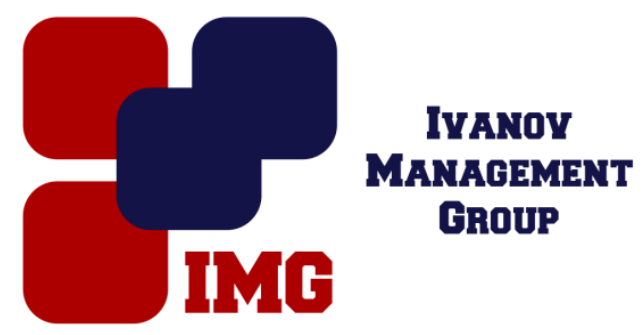

Kalenov A.A.

doi: $10.18411 / 1 \mathrm{j}-30-06-2017-38$

idsp 000001:1j-30-06-2017-38

\section{To the issue of the empirical study of the level of formation of subjectivity of senior schoolchildren}

\begin{abstract}
Annotation
The article discloses the generalization of methodological tools for the capacity to act diagnostics among senior schoolchildren, in accordance with the author's understanding of the capacity to act. A brief description of the modification of the methodology for studying the structure of the capacity to act for use in the sample of teenagers and senior schoolchildren is given in this paper. The subject matter of the methodological support package for the capacity to act formation diagnostics among senior schoolchildren is described, as well as a short step-by-step algorithm for data processing and derivation the integral level indicator of the capacity to act formation based on the obtained numerical values of separate components.

Keywords: capacity to act, components of the capacity to act among senior schoolchildren, capacity to act diagnostics, methods of diagnostics of the capacity to act among senior schoolchildren.

In the contemporary world, in various spheres of life and activity, a personality as a possessor of unique features and ways of activity implementation comes to the fore. The concept of personality itself is undoubtedly widely represented in modern science, and any interpretations of its subject matter include the same variables and criteria of definition: social conditioning, involvement in social space (belonging to a particular society and efficient existence in it), activity, awareness, responsibility, etc. Personality, as a specific social product, has a uniform understanding in science and is
\end{abstract}


expressed by the axiomatic phrase: "one is not born a personality, one becomes a personality". Developing in the context of a certain socio-cultural and historical space, a person is the bearer of certain, peculiar to him, views, moral norms and values, philosophy of life. However, together with the concept of personality, as it is understood and accepted by the majority, a category of the capacity to act appears in science, and the absence of a uniform understanding of it generates some terminological confusion. The capacity to act, in the most general definition, is a feature of the personality that arises at a certain stage of its development as an expression of the ability to be a subject. The capacity to act does not exist apart from the personality, and it is one of its key characteristics. As distinctive features of the subject, in turn, researchers identify different units of analysis and options for methodological support of empirical research of the capacity to act.

The category of the capacity to act is considered from the point of view of various approaches and concepts as a feature, a specific characteristic of the personality (E.N. Volkova, S.D. Deryabo, V.A. Petrovsky, I.A. Seregina, etc.) as a function of the personality for implementation an activity of certain nature (V.I. Slobodchikov, E.I. Isaev, S.Z. Goncharov, N.V. Popova, etc.), as the highest level of expression of the ability to regulate behavior (M.V. Ermolaeva, P.V. Kondratieva, S.Z. Goncharov, N.V. Popova, A.K. Osnitsky, V.A. Petrovsky, V.O. Tatenko, etc.), as a prerequisite for and the way of personality development (A.A. Bodalev), etc. Common to all interpretations, in one aspect or another, is understanding of the capacity to act as a characteristic inherent to a personality as a social product and realized exclusively in the social space during activity expression [2]. Having analyzed a number of the above-mentioned and other (A.A. Bodalev, S.Z. Goncharov, N.V. Popova, S.D. Deryabo, M.V. Ermolaeva, P.V. Kondratieva, A.K. Osnitsky, V.A. Petrovsky, V.I. Slobodchikov, E.I. Isaev, V.O. Tatenko, etc.) models and approaches to the definition of the capacity to act and its structure, it is worth noticing some common points:

1) conscious activity relatively to one's self, the world around and activity is recognized as the central characteristic of the capacity to act;

2) accepting oneself as a subject, possessing certain characteristics (responsibility, relative autonomy, integrity, independence, etc.), as well as recognition the right of others to be subjects and to demonstrate subjective qualities;

3) experience of the value and uniqueness of oneself [2].

Understanding of the category of "capacity to act" as itself, can be considered as a feature of personality, as a function of it, and as a specific form of self-regulation and conscious activity. Having generalized the results of the theoretical analysis, we 
accepted the following definition for the capacity to act: capacity to act is a systemforming central feature of a personality, that arises at a certain stage of its development and expresses itself in a specifically human conscious and active attitude to the world around and to oneself. The structure of the capacity to act includes as follows: awareness of activity, ability to goal-setting, self-regulation of activity and behavior, reflexivity, responsibility, self-awareness as a subject and unique personality and recognition of the same in other people [2].

In accordance with the proposed technology of the capacity to act formation among senior schoolchildren, it is necessary to monitor the level of the capacity to act formation at the initial and final stages of work on the selected components of the capacity to act [3]. Difficulties of methodical support consist in missing of the uniform instrument for diagnostics of the personality's capacity to act, as for the present time, but it is possible to use a package of complementary methodologies, the results of which can give a holistic view of the formation of individual components and the capacity to act in general. Having analyzed properly the means of diagnostics, available in the scientific and methodological literature, we formed the following package of methodological support for the capacity to act formation diagnostics among senior schoolchildren (table 1).

The contents of the package of methodological support for the capacity to act formation diagnostics among senior schoolchildren

\begin{tabular}{|c|c|c|}
\hline $\begin{array}{c}\text { Components of the capacity to } \\
\text { act }\end{array}$ & Studying indicators & Methodologies \\
\hline $\begin{array}{l}\text { Awareness of activity, } \\
\text { reflexivity, responsibility, self- } \\
\text { awareness as a subject and } \\
\text { unique personality and } \\
\text { recognition of the same in other } \\
\text { people }\end{array}$ & $\begin{array}{l}\text { Levels of activity, ability to self- } \\
\text { reflection, freedom of choice } \\
\text { and responsibility for it, } \\
\text { awareness of one's uniqueness, } \\
\text { understanding and acceptance of } \\
\text { others, readiness for self- } \\
\text { development }\end{array}$ & $\begin{array}{l}\text { Questionnaire for studying the } \\
\text { structure of the capacity to act } \\
\text { by E.N. Volkova, I.A. Seregina } \\
\text { (in our own modification for } \\
\text { teenagers and senior } \\
\text { schoolchildren) }\end{array}$ \\
\hline Personal control & $\begin{array}{c}\text { Level and orientation } \\
\text { (internal/external) of personal } \\
\text { control }\end{array}$ & $\begin{array}{c}\text { Methodology "Personal control } \\
\text { level” by E.F. Bazhin, E.A. } \\
\text { Golynkina, L.M. Etkind. }\end{array}$ \\
\hline Conscious self-regulation & $\begin{array}{c}\text { Level of development of } \\
\text { conscious self-regulation of } \\
\text { activity and behavior }\end{array}$ & $\begin{array}{l}\text { Questionnaire "Style of self- } \\
\text { regulation of behavior" by V.I. } \\
\text { Morosanova }\end{array}$ \\
\hline $\begin{array}{l}\text { Attitude to oneself as to a } \\
\text { subject of activity, ability to } \\
\text { goal-setting }\end{array}$ & $\begin{array}{c}\text { Awareness of the goals, } \\
\text { satisfaction with self-realization, } \\
\text { the locus of control (I/life), life } \\
\text { conciseness }\end{array}$ & $\begin{array}{c}\text { Test "Life-purpose orientations" } \\
\text { by D.A. Leontiev }\end{array}$ \\
\hline
\end{tabular}

Table 1 shows that package of methodological support for the capacity to act formation diagnostics among senior schoolchildren, formed by us, includes preferably well-known, standardized and reliable methodologies (Methodology "Personal control level" by E.F. Bazhin, E.A. Golynkina, L.M. Etkind; Questionnaire "Style of self- 
regulation of behavior" by V.I. Morosanova; test "Life-purpose orientations" by D.A. Leontiev), to focus on which separately within the framework of this article is inexpedient. Most of the components of the capacity to act (awareness of activity, reflexivity, responsibility, self-awareness as a subject and unique personality and recognition of the same in other people) are diagnosed, according to the proposed package, using the questionnaire for studying the structure of the capacity to act, by E.N. Volkova and I.A. Seregina [1; 4] in our own modification. Let us further consider the content aspects of this methodology and the specifics of the modification we have made.

The questionnaire for studying the structure of the capacity to act, by E.N. Volkova and I.A. Seregina, is intended for adults (teachers) [1; 4]. Despite the fact that most of the questionnaire's statements are fairly neutral and suitable for senior schoolchildren by semantic meaning, some statements still needed to be adjusted. Below are the items of the questionnaire that we modified for use in the sample of senior schoolchildren (Table 2).

Table 2

Modification of the items of the questionnaire for studying the structure of the capacity to act by E.N. Volkova, I.A. Seregina for use in the sample of senior schoolchildren

\begin{tabular}{|c|c|c|}
\hline $\begin{array}{c}\text { Initial statements of the } \\
\text { questionnaire }\end{array}$ & Modified formulation & Substantiation of the formulation \\
\hline $\begin{array}{l}\text { 16. Are you an independent } \\
\text { person? }\end{array}$ & $\begin{array}{c}\text { 16. Are you able to make } \\
\text { decisions based on your own } \\
\text { preferences and internal } \\
\text { needs? }\end{array}$ & $\begin{array}{l}\text { Independence for a senior school } \\
\text { child is most often limited by the } \\
\text { material and moral dependence on } \\
\text { the parents' family, age } \\
\text { restrictions, etc. }\end{array}$ \\
\hline $\begin{array}{l}\text { 24. Do you have the talent of a } \\
\text { leader? }\end{array}$ & $\begin{array}{c}\text { 24. Can you manage any } \\
\text { activity in a group of age- } \\
\text { mates? }\end{array}$ & $\begin{array}{c}\text { In our opinion, for teenagers and } \\
\text { senior schoolchildren there are not } \\
\text { many life situations where the } \\
\text { talent of a leader can be } \\
\text { demonstrated. To make it easier to } \\
\text { answer the question, without } \\
\text { change of its semantic meaning, } \\
\text { we have narrowed the scope of } \\
\text { leadership to a group of age- } \\
\text { mates. }\end{array}$ \\
\hline $\begin{array}{l}\text { 28. Does your job meet your } \\
\text { internal requirements? }\end{array}$ & $\begin{array}{l}\text { 28. Does your occupation } \\
\text { meet your internal } \\
\text { requirements and needs? }\end{array}$ & \multirow{2}{*}{$\begin{array}{l}\text { The semantic units "job" and } \\
\text { "professional" do not correspond } \\
\text { to the considered age range, } \\
\text { because the absolute majority of } \\
\text { senior schoolchildren is not } \\
\text { involved in any professional } \\
\text { activity, job as paid work. }\end{array}$} \\
\hline $\begin{array}{l}\text { 55. Do you aim to improve your } \\
\text { professional level? }\end{array}$ & $\begin{array}{l}\text { 55. Do you aim to reach new } \\
\text { level, develop your skills in } \\
\text { your favorite activities? }\end{array}$ & \\
\hline $\begin{array}{c}\text { 61. Do you prefer improvising } \\
\text { in class? (Note: in pedagogical } \\
\text { activity) }\end{array}$ & $\begin{array}{l}\text { 61. Do you have a desire to } \\
\text { improvise in various life } \\
\text { situations and activities? }\end{array}$ & $\begin{array}{l}\text { The semantic meaning of the } \\
\text { statement is preserved, but the } \\
\text { range of possible improvisation } \\
\text { spheres is expanded, because } \\
\text { frequently a lesson is not a } \\
\text { suitable form of activity for a } \\
\text { senior school child, where } \\
\text { improvisation is supported and } \\
\text { welcomed. }\end{array}$ \\
\hline
\end{tabular}


Thus, we have made a formal modification of the separate statements of the questionnaire with respect to semantic units that do not match the age of senior schoolchildren, with the preservation of the general sense. At the same time, in all the statements of the questionnaire, pronouns were replaced as follows: formal "you" with informal "thee", formal "your" with informal "thy", etc. This was done for the purpose of less formalizing the diagnostic procedure, reducing emotional tension, because these pronouns are used most often when referring to senior schoolchildren. Preservation, during the modification, of all the statements of the questionnaire by E.N. Volkova, I.A. Seregina with their semantic meaning unchanged, allowed to preserve the original author's key to the methodology, as a result of which data processing also allows obtaining information about the level of formation of such components of the capacity to act as awareness of activity, reflexivity, responsibility, self-awareness as a subject and unique personality and recognition of the same in other people. Pilot application of our modification of the questionnaire by E.N. Volkova, I.A. Seregina in a small sample of senior schoolchildren (52 persons), followed by a discussion with them the content of separate statements, showed that tested schoolchildren have proper understanding of the meaning of the questions, as well as a sufficiently developed self-reflection and self-awareness to answer them.

The proposed package of methodological support for capacity to act formation diagnostics among senior schoolchildren allows us to determine the level indicators of separate components, but does not answer the question about the formation of the capacity to act as an integral phenomenon. Therefore, it is necessary to integrate indicators by separate components, which will allow us to derive a single indicator of the capacity to act of a senior school child. For this purpose, it is expedient to implement the following steps:

- converting the numerical data for each indicator of the capacity to act into a scale of 1 to 10 (sten scale) using the standardization method;

- summarizing the sten values of all indicators of the capacity to act, the values obtained after standardization, and derivation of their average arithmetic, which is an assessment of the level of the capacity to act formation by a scale of 1 to 10 .

It is also seems to be useful to supplement the obtained indicator of the capacity to act with the profile of the capacity to act of senior schoolchildren, which can be represented visually as a graph, a column or a petal histogram, the ratio of all components of the capacity to act (in the sten values, obtained after standardization), which clearly shows which of them are formed to a greater, and which to a lesser extent. Such presentation of the results, in our opinion, will give a complete view of 
the studied feature and allow more efficient implementation of the technology of the capacity to act formation.

Thus, the package of methodological support for the capacity to act formation diagnostics among senior schoolchildren includes means for obtaining empirical data in connection with separate structural components of the capacity to act (awareness of activity, ability to goal-setting, self-regulation of activity and behavior, reflexivity, responsibility, self-awareness as a subject and unique personality and recognition of the same in other people). The processing of diagnostic data involves the construction of a profile of the components of the capacity to act and the derivation of an integral level indicator of the formation of the capacity to act based on the standardization of initial numerical data in the sten scale.

$* * *$

1. Volkova, E.N. Capacity to act by a teacher: theory and practice: Author's thesis of Doctor of psychological sciences: 19.00.07 [Electronic resource] / E.N. Volkova. - Moscow: PI RAO, 1998. - 50 p. - URL: http://www.dslib.net/psixologia-vozrasta/subektnost-pedagoga.html.

2. Kalenov, A.A. Referring to the issue of understanding of the capacity to act and its structure in scientific research [Electronic resource] / A.A. Kalenov // Education and training. - 2017. No.1. - P. 3-7. - URL: https://moluch.ru/th/4/archive/52/1930/.

3. Kalenov, A.A. Subject matter of technology for creating situations of success for the capacity to act formation among senior schoolchildren in terms of the education process at school [Electronic resource] / A.A. Kalenov // Humanitarian tractate. - 2017. - No. 7. - P. 10-13. URL: http://gumtraktat.ru/wp-content/uploads/v7.pdf.

4. Seregina, I.A. Psychological structure of the capacity to act as a personal characteristic of the teacher: Author's thesis of Candidate of psychological sciences: 19.00.07 [Electronic resource] / I.A. Seregina. - Moscow: PI RAO, 1999. - 26 p. - URL: http://www.dslib.net/psixologiavozrasta/psihologicheskaja-struktura-subektivnosti-kak-lichnostnogo-svojstva-pedagoga.html. 